\title{
PENINGKATAN KEMAMPUAN MENGENAL KOSAKATA BAHASA ARAB MELALUI METODE PEMBELAJARAN PICTURE AND PICTURE SISWA KELAS IB MI NURUL ANWAR BEKASI UTARA
}

\author{
Fiyani Nabilah \\ M. Abdul Gofur
}

\author{
Sekolah Tinggi Agama Islam (STAI) Bani Saleh \\ Jln. M. Hasibuan No.68 (Lantai 2) Bekasi Timur 17113, Telp/Fax : 021-883 43360 \\ www.staibanisaleh.ac.id e-mail : staibanisaleh@yahoo.co.id \\ nabilahfiyani12@gmail.com.,opng38@gmail.com
}

Naskah masuk: 16-05-20, direvisi: 21-05-20, diterima: 16-05-20, dipublikasi: 30-04-20

\begin{abstract}
Abstrak: Penelitian ini bertujuan untuk mendapatkan gambaran-gambaran serta informasi tentang peningkatan kemampuan mengenal kosakata bahasa Arab melalui metode pembelajaran picture and picture siswa kelas IB MI Nurul Anwar Bekasi Utara. Fokus pada penelitian ini adalah mencari solusi terhadap permasalahan kelas terkait dengan proses peningkatan kemampuan mengenal kosakata bahasa Arab melalui metode pembelajaran picture and picture pada materi mengenal 20 kosakata bahasa Arab tentang hewan dan buah. Penelitian pada permasalahan ini dilakukan dengan menggunakan penelitian tindakan kelas yang menjadikan penggunaan metode pembelajaran picture and picture sebagai intervensi tindakan dan kemampuan mengenal kosakata bahasa Arab sebagai dampak yang diamati.
\end{abstract}

Kata kunci: Kemampuan, Kosakata Bahasa Arab, Picture and Picture.

\begin{abstract}
This study aims to obtain images and information about improving the ability to recognize Arabic vocabulary through picture and picture learning methods for students of class 1B MI Nurul Anwar North Bekasi. The focus of this research is to find solutions to class problems related to the process of increasing the ability to recognize Arabic vocabulary through the method of learning picture and picture on the material to recognize 20 Arabic language covabulary of animals and fruits. Reseacrh on this problem was carried out using classroom action research that made the use of picture and picture learning methods as action interventions and the ability to recognize Arabic vocabulary as observed impacts.
\end{abstract}

Keywords: Ability, Arabic vocabulary, Picture and Picture.

\section{PENDAHULUAN}

Pembahasan tentang pendidikan di dalam Islam, tentu tidak terlepas dari pembahasan mengenai bahasa Arab. Hal ini karena sumber utama agama Islam yaitu Al-Qur'an dan Hadits, keduanya menggunakan bahasa Arab. Menimbang posisinya sebagai bahasa Al Qur'an dan Hadits, tentunya bahasa Arab menjadi salah satu yang harus dipelajari, dikuasai atau minimal dipahami oleh seorang muslim agar ia dapat memahami hukum-hukum dari syariat Islam dengan baik tanpa menyimpang dari makna yang ada dalam Al-Qur'an dan Hadits.

Tentang pentingnya belajar bahasa Arab, Shabahat Nabi yang bernama Umar bin Khattab Radhiyallahu 'anhu pernah berkata:

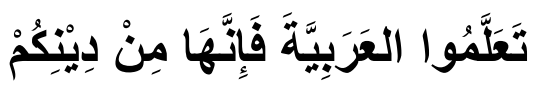


"Belajarlah bahasa Arab, karena sesungguhnya bahasa Arab itu adalah bagian dari agama kalian".

Bahasa merupakan jembatan ilmu pengetahuan. Dengan menguasai banyak bahasa kita bisa mempelajari banyak ilmu pengetahuan. Bahasa Arab adalah sebuah bahasa yang terbesar dari segi jumlah penutur dalam keluarga bahasa semitik. Bahasa ini berkerabat dekat dengan bahasa Ibrani dan bahasa Aram. Bahasa Arab modern telah diklasifikasikan sebagai satu makrobahasa dengan 27 subbahasa dalam 150 639-3. Bahasa-bahasa ini dituturkan di seluruh dunia Arab, sedangkan bahasa Arab baku diketahui di seluruh dunia Islam. Bahasa Arab modern berasal dari bahasa Arab klasik yang telah menjadi bahasa kesusastraan dan agama islam sejak lebih kurang abad ke-6. Abjad Arab ditulis dari kanan ke kiri (Acep Hermawan, 2014:26). Di Indonesia sendiri, Bahasa Arab merupakan bahasa asing karena bukan menjadi bahasa pergaulan sehari-hari.

Menurut Al-Ghalayin (dalam Acep Hermawan, 2014:25), bahasa Arab adalah kalimat-kalimat yang dipergunakan oleh orang-orang Arab untuk mengungkapkan tujuan-tujuan (pikiran dan perasaan) mereka. Bahasa Arab telah memberi banyak kosakata kepada bahasa lain dari dunia islam, sama seperti peranan Latin kepada kebanyakan bahasa Eropa. Semasa abad pertengahan, bahasa Arab juga merupakan alat utama budaya, terutama dalam sains, matematika, dan filsafat, yang menyebabkan banyak bahasa Eropa turut meminjam banyak kosakata dari bahasa Arab.

Di era globalisasi saat ini, salah satu sarana komunikasi yang berperan penting dan diperlukan untuk kompetisi global adalah penguasaan Bahasa Asing. Pembelajaran bahasa asing yang dapat dikenali sejak usia dini salah satunya adalah Bahasa Arab. Dengan mengenalkan kosakata bahasa Arab sejak usia dini untuk menyiapkan kematangan kepada anak sebagai jembatan dalam mengenal ilmu agama Islam.
Kosakata bahasa Arab (mufradat) sebagai salah satu bagian penting dari komponen bahasa, baik penggunaan bahasa secara lisan maupun secara tertulis, dan merupakan salah satu pengembangan kemampuan berbahasa Arab (Abdul Hamid, 2010:33). Kosakata diartikan sebagai perbendaharaan kata dalam berbagai bentuknya yang meliputi kata-kata lepas dengan atau tanpa imbuhan, dan kata-kata yang merupakan gabungan dari kata-kata yang sama atau berbeda, masing-masing dengan artinya sendiri (M. Soenardi Djiwandono, 2008:126).

Dapat dikatakan juga bahwa kosakata adalah inti atau bagian pokok dari bahasa. Sebab, pada hakikatnya, bahasa adalah kumpulan dari kosakata. Ketika seseorang akan memahami sebuah teks, paling tidak ia harus mengetahui jenis kata dan fungsinya secara umum. Setidaknya, ia mampu membedakan suku kata dengan yang lainnya (Nurul Huda, 2012:38). Jadi, kemampuan membedakan suku kata akan memperkaya pemahaman anak untuk mengenal suatu bahasa.

Agar pembelajaran kosakata bisa berjalan dengan optimal, diperlukan sebuah metode pembelajaran yang inovatif dan efektif, diantaranya adalah metode pembelajaran picture and picture.

Metode pembelajaran picture and picture adalah suatu metode belajar yang menggunakan gambar dan dipasangkan atau diurutkan menjadi urutan logis. Pembelajaran ini memiliki ciri aktif, inovatif, kreatif dan menyenangkan. Jumanta Hamdayama (2017:229) menjelaskan bahwa metode picture and picture merupakan sebuah metode pembelajaran dimana guru menggunakan alat bantu atau media gambar untuk menerangkan sebuah materi atau memfasilitasi siswa untuk aktif belajar. Dengan menggunakan alat bantu atau media gambar, diharapkan siswa mampu mengikuti pelajaran dengan fokus yang baik dan dalam kondisi yang menyenangkan, sehingga apapun pesan yang disampaikan, bisa diterima dengan baik dan mampu meresap dalam hati, serta dapat diingat kembali oleh siswa. 
Berdasarkan hasil observasi di MI Kelas 1B Nurul Anwar Bekasi Utara penulis menemukan adanya masalah yaitu dalam kegiatan pengenalan bahasa Arab, anak masih kurang menguasai kosakata bahasa Arab dan rendahnya semangat anak dalam menyebutkan dan mengikuti ucapan guru dalam pembelajaran bahasa Arab.

Untuk meningkatkan kemampuan anak dalam mengenal kosakata bahasa Arab, penulis menggunakan metode pembelajaran picture and picture dengan harapan agar tercapai pembelajaran yang menyenangkan bagi anak, sehingga perkembangan anak dalam mengenal kosakata bahasa Arab dapat tercapai sesuai dengan yang diharapkan.

Adapun materi dalam penelitian ini menekankan pada 20 kosakata bahasa Arab tentang buah-buahan dan hewan.

\section{METODE}

Metode yang digunakan dalam penelitian ini adalah jenis Penelitian Tindakan Kelas (Classroom Action Research) dengan pendekatan kualitatif dan kuantitatif. Ekawarna (2010:4) berpendapat bahwa penelitian kelas yang berarti penelitian tindakan (Action Research) yang dilakukan oleh guru di dalam kelas untuk mengetahui akibat tindakan yang diharapkan pada suatu subjek penelitian di kelas tersebut.

Menurut Igak Wardhani dan Kusmaya Wihardit (2012:1.3) bahwa penelitian tindakan adalah penelitian yang dilakukan oleh guru di dalam kelasnya sendiri melalui refleksi diri dengan tujuan untuk memperbaiki kinerjanya sebagai guru, sehingga hasil belajar siswa menjadi meningkat.

Sedangkan menurut Suharsimi Arikunto (2013:3) ada beberapa cara penelitian tindakan kelas yang bisa dilakukan, diantaranya yaitu Description Research, Penelitian Korelasi, Penelitian Komparasi, Penelitian Penelusuran.

Pada penelitian tindakan kelas ini, digunakan skema Kemmis dan Mc. Taggart (dalam Arikunto, 2013:16) yang meliputi tahap-tahap sebagai berikut: perencanaan (planning), (b) tindakan (acting), (c) observasi (observing), (d) reflesi (reflecting). Begitu seterusnya hingga membentuk spiral (Hasanah, Lathipah, 2018).

Dengan demikian konsep yang digunakan dalam penelitian ini adalah peningkatan kemampuan mengenal kosakata bahasa Arab melalui metode pembelajaran picture and picture dengan cara; siklus pertama, mengidentifikasi masalah yang diangkat oleh peneliti sebagai penelitian, menemukan fakta-fakta yang menjadi fokus penelitian, merencanakan tindakan, mengobservasi proses tindakan, mengumpulkan data, menganalisis data, menyusun hipotesis, melakukan tindakan, mengobservasi proses tindakan, dan menuliskan hasil penemuan. Jika penulis belum menemukan hasil maksimal, maka penelitian dilanjutkan ke siklus berikutnya sampai peneliti menumukan hasil maksimal.

Sumber data dalam penelitian ini adalah siswa kelas 1B MI Nurul Anwar Bekasi Utara yang berjumlah 35 siswa. Kolaborator dalam penelitian ini adalah guru bidang studi bahasa Arab yang dinilai memahami tentang kriteria anak mengenai kemampuan mengenal kosakata bahasa Arab. Penulis juga melibatkan teman sejawat sebagai pengamat dan dokumentasi dan juga penulis sebagai pelaksanaan tindakan.

\section{HASIL DAN PEMBAHASAN}

\section{A. Deskripsi Data Assesmen Awal}

Kegiatan yang dilakukan penelitian pada penelitian tindakan kelas ini disesuaikan dengan tahap perencanaan yang telah dibuat dan ditentukan oleh peneliti pada perencanaan penelitian. Sesuai dengan rencana yang telah ditentukan, maka penulis mengawali penelitian dengan mengadakan pertemuan awal dengan pihak MI Nurul Anwar Bekasi Utara yaitu kepala sekolah, guru kelas 1B dan guru bidang studi untuk membahas langkah-langkah penelitian tindakan kelas (PTK) yang akan dilaksanakan. 
Sebelum tahapan-tahapan siklus dilaksanakan, penulis melakukan persiapan prapenelitian terlebih dahulu. Prapenelitian dilakukan dengan cara mencari dan mengumpulkan data-data siswa yang akan diteliti melalui observasi langsung dan melakukan pretest untuk mengetahui sejauh mana kondisi awal kemampuan mengenal kosakata bahasa Arab siswa kelas IB pada materi mengenal 20 kosakata hewan dan buah-buahan.

Pemberian pretest pada siswa kelas IB bertujuan untuk melihat kemampuan mengenal kosakata bahasa Arab siswa yang selanjutnya akan diberikan tindakan. Berdasarkan pengamatan, kemampuan mengenal kosakata bahasa Arab siswa sangat bervariatif dan masih banyak siswa yang memperoleh nilai dibawah kriteria ketuntasan minimal (KKM) yaitu 75 yang telah ditentukan. Adapun hasil assesmen awal adalah sebagai berikut:

Tabel 1. Hasil Assesmen Awal

\begin{tabular}{lcc} 
& Skor & Prosentase \\
\hline Jumlah & 476 & 2060 \\
Rata-rata & 13 & 58 \\
Tercapai & 8 & 22 \\
Belum & 27 & 77 \\
Tercapai & & \\
Keterangan & \multicolumn{2}{c}{ Belum Tuntas } \\
\hline
\end{tabular}

Disimpulkan bahwa hanya 8 siswa yang memenuhi $\mathrm{KKM}$ atau $22 \%$ siswa yang tercapai dan 27 siswa yang masih dibawah $\mathrm{KKM}$ atau $77 \%$ siswa yang belum tercapai dalam hasil mengenal kosakata bahasa Arab siswa kelas IB MI Nurul Anwar Bekasi Utara, sedangkan standar Kriteria Ketuntasan Minimal (KKM) yang ditetapkan dalam penelitian ini yaitu 75 . Oleh karena itu, penulis merencanakan kegiatan tindakan kelas pada pembelajaran yang direncanakan pada siklus I.

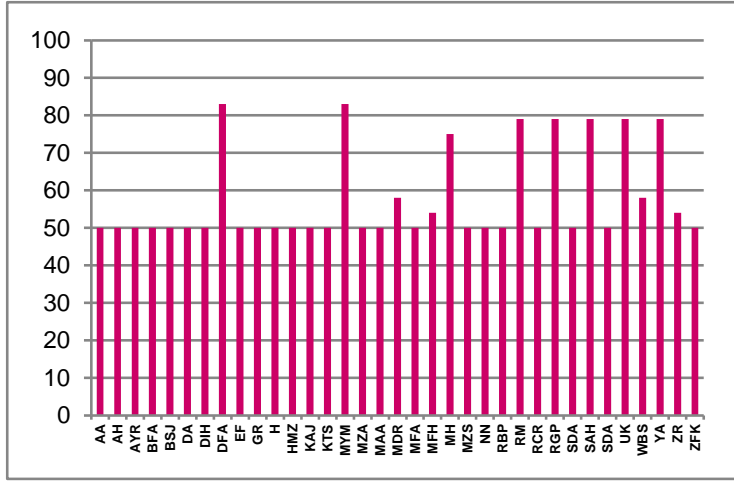

\section{Gambar 1. Grafik Hasil Data Assesmen Awal \\ Sumber: Skripsi (2019:91)}

Dapat dilihat bahwa perolehan nilai tersebut menunjukkan hasil kemampuan mengenal kosakata bahasa Arab siswa masih rendah dan kurang dari target yang diharapkan. Data assesmen awal telah menunjukkan bahwa hanya hanya 8 subjek penelitian dari 35 subjek penelitian siswa kelas IB MI Nurul Anwar Bekasi Utara dengan mencapai nilai kriteria ketuntasan minimal (KKM) yaitu 75. Sedangkan terdapat 27 subjek penelitian yang belum menunjukkan kemampuan mengenal kosakata bahasa Arab. Hal ini dapat dilihat dari skor yang diperoleh masing-masing siswa dan prosentase rata-rata yang dicapai dalam kegiatan ini hanya 58.

\section{B. Deskripsi Data Siklus I}

Pada siklus I, tindakan yang diberikan dilakukan secara bertahap yaitu selama 4 kali pertemuan. Setiap kali pertemuan berlangsung selama 70 menit atau dua jam mata pelajaran. Adapun peran penulis dalam penelitian ini adalah sebagai pemberi tindakan dan sebagai pengamat. Sehingga penulis terlibat langsung bersama siswa dalam upaya meningkatkan kemampuan mengenal kosakata bahasa Arab melalui metode pembelajaran picture and picture.

Dari hasil pengamatan terhadap tindakan pada siklus I ini, secara keseluruhan tindakan yang diberikan kepada siswa sudah cukup baik, akan tetapi masih ada kekurangan dalam memberikan tindakan pembelajaran kepada siswa, 
diantaranya: belum menarik perhatian siswa secara keseluruhan sehingga siswa belum antusias dalam mengikuti pembelajaran, belum maksimal dalam memberikan contoh, belum bisa mengontrol dengan baik suasana kelas sehingga menjadi kurang kondusif, belum maksimal dalam memantau dan membimbing siswa dalam melafalkan kosakata yang sudah dipelajari. Dengan adanya hasil pengamatan pada siklus I ini, diharapkan akan ada perbaikan tindakan pada siklus berikutnya.

Begitu juga dengan hasil data observasi siswa, secara umum masih terdapat indikator yang dianggap belum mencapai target yang telah ditentukan, yaitu siswa belum memahami langkah-langkah kegiatan pembelajaran bahasa Arab melalui metode pembelajaran picture and picture sehingga masih banyak siswa yang merasa kesulitan dalam mengikuti pelajaran.

Adapun hasil tes kemampuan siswa pada siklus I adalah sebagai berikut:

Tabel 2. Hasil Data Siklus I

\begin{tabular}{lcc} 
& Skor & Prosentase \\
\hline Jumlah & 505 & 2525 \\
Rata-rata & 14 & 72 \\
Tercapai & 18 & 51 \\
Belum & 17 & 48 \\
Tercapai & & \\
Keterangan & Belum Tuntas \\
\hline
\end{tabular}

Diketahui bahwa terdapat 18 siswa yang sudah memenuhi KKM atau 51\% siswa tercapai dan terdapat 17 siswa yang belum memenuhi $\mathrm{KKM}$ atau $48 \%$ siswa belum tercapai. Peningkatan kemampuan mengenal kosakata bahasa Arab siswa kelas IB MI Nurul Anwar Bekasi Utara setelah diberikan tindakan pada siklus I rata-rata 72 mengalami kenaikan yang baik jika dibandingkan dengan rata-rata kelas pada assesmen awal yaitu 58. Maka didapatkan prosentase kenaikan sebesar 14.
Berikut penulis menyajikan data penelitian siklus I dalam bentuk grafik:

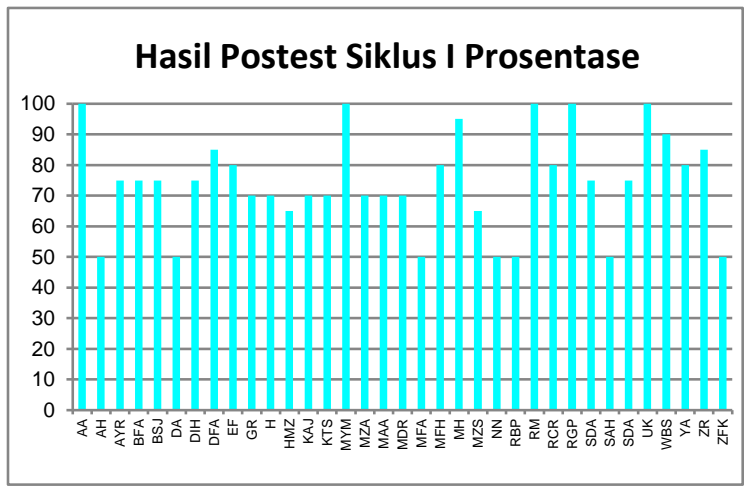

\section{Gambar 2. Grafik Hasil Data Siklus I Sumber: Skripsi (2019:106)}

Pengamatan dan refleksi didapat hasil yang cukup baik, hasil dari pengamatan penulis tersebut memperlihatkan adanya perubahan hasil kemampuan mengenal kosakata bahasa Arab siswa kelas IB MI Nurul Anwar Bekasi Utara menjadi lebih baik dan meningkat dibandingkan dengan data sebelum dilakukannya tindakan dengan nilai prosentase sebesar 58, sedangkan dari hasil penelitian yang diberi tindakan oleh penulis pada tindakan siklus I ini mencapai nilai prosentase sebasar 72 , namun masih dikatakan belum mencapai target KKM yang ditentukan yaitu 75 .

Dengan demikian penelitian harus dilanjutkan ke siklus II dengan perbaikan perencanaan dan tindakan yang disesuaikan dengan kebutuhan dalam penelitian.

\section{Deskripsi Data Siklus II}

Pelaksanaan tindakan pada siklus II dilakukan sebanyak empat kali pertemuan dengan durasi 2x35 menit dan merupakan pelaksanaan perbaikan perencanaan dari siklus I. Dari hasil pengamatan terhadap tindakan guru pada siklus II ini, secara keseluruhan tindakan yang diberikan kepada siswa sudah sangat baik, akan tetapi masih ditemukan satu kekurangan dalam memberikan tindakan pembelajaran kepada siswa, diantaranya: belum memberikan penguatan kepada siswa 
dengan reward disaat siswa berhasil mengikuti pembelajaran mengenal kosakata bahasa Arab.

Sedangkan dilihat dari proses pembelajaran yang dilaksanakan pada siklus II ini, kegiatannya dapat berjalan dengan baik dan lancar, hal ini terlihat dari antusias dan semangat yang ditunjukkan oleh siswa selama proses kegiatan belajar berlangsung. Semua siswa berperan aktif dalam kegiatan belajar, berkomunikasi, interaksi, mengajukan pertanyaan maupun menjawab pertanyaan yang diberikan kepada meraka.

Sedangkan hasil pengamatan terhadap kemampuan kosakata bahasa Arab siswa adalah sebagai berikut:

Tabel 3. Hasil Data Siklus II

\begin{tabular}{lcc}
\hline & Skor & Prosentase \\
\hline Jumlah & 622 & 3010 \\
Rata-rata & 17 & 88 \\
Tercapai & 35 & 100 \\
Belum & - & - \\
Tercapai & & \\
Keterangan & & \multicolumn{2}{c}{ Tuntas } \\
& & \\
\hline
\end{tabular}

Seluruh siswa telah memenuhi KKM (Kriteria Ketercapaian Minimum) yang telah ditentukan yaitu 75 , untuk hasil kemampuan mengenal kosakata bahasa Arab melalui metode pembelajaran picture and picture dengan memperoleh nilai rata-rata 17 dengan prosentase sebesar $88 \%$. Pada siklus II ini, nilai tertinggi terdapat pada angka 100 dan nilai terendah terdapat pada angka 75. Dengan demikian 35 siswa yang menjadi subjek penelitian ini sudah meningkat dan tercapai sesuai dengan hasil tindakan yang diharapkan, yaitu KKM sebesar 75. Oleh karena itu, penelitian ini dianggap sudah berhasil dan tindakan dihentikan.

Berikut ini penulis menyajikan hasil data penelitian pada siklus II dalam bentuk grafik:

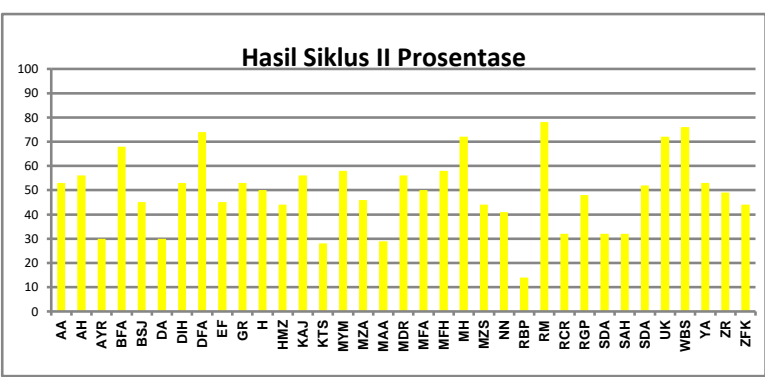

\section{Gambar 3. Grafik Hasil Data Siklus II} Sumber: Skripsi (2019, hlm. 121)

\section{Perbandingan Hasil Assesmen Awal, Siklus I dan Siklus II}

Penulis melakukan perbandingan hasil data mulai dari assesmen awal, siklus I hingga ke siklus II, hasilnya sebagai berikut:
Tabel 4. Perbandingan Hasil Nilai Rata- rata Assesmen Awal, Siklus I dan Siklus II

\begin{tabular}{lcc}
\hline \multicolumn{1}{c}{ Keterangan } & Prosentase & Kenaikan \\
\hline Assesmen Awal & $58 \%$ & \multirow{2}{*}{$15 \%$} \\
Siklus I & $73 \%$ & \\
Siklus I & $73 \%$ & \multirow{2}{*}{$14 \%$} \\
Siklus II & $87 \%$ & \\
\hline
\end{tabular}

Perbedaan tersebut bisa diihat dalam grafik berikut:

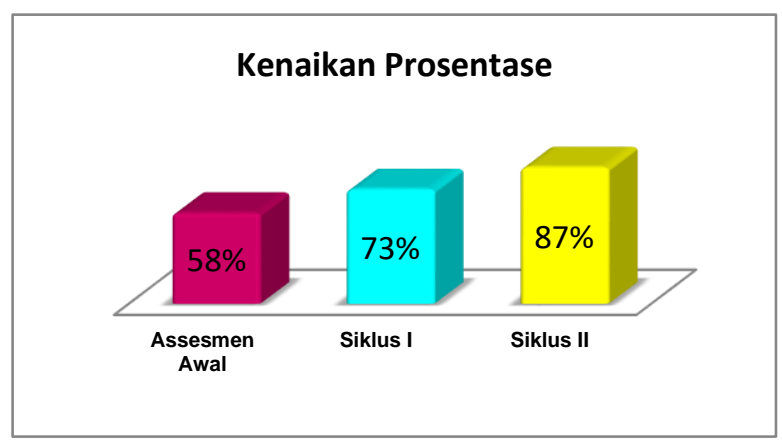

\section{Gambar 4. Perbandingan prosentase Sumber: Skripsi (2019, hlm.137)}

Serangkaian tindakan pelaksanaan penelitian yang dilakukan pada tes assesmen awal, siklus I, siklus II memperlihatkan tercapainya hasil penelitian tindakan yang diharapkan, yaitu 
meningkatkan kemampuan mengenal kosakata bahasa Arab kelas IB MI Nurul Anwar Bekasi Utara. Kemampuan mengenal kosakata bahasa Arab saat assesmen awal dengan rata-rata kelas sebesar $58 \%$, mengalami peningkatan setelah diberi tindakan pada siklus I dengan rata-rata kelas sebesar $72 \%$. Kemudian mengalami peningkatan lagi setelah diberi tndakan pada siklus II dengan rata-rata kelas $88 \%$. Adapun prosentase kenaikan dari assesmen awal ke siklus I sebesar $14 \%$, dan prosentase kenaikan siklus I ke siklus II sebesar 16\%. Sehingga dapat disimpulkan bahwa prosentase rata-rata kelas dari assesmen awal sampai siklus II mencapai $30 \%$. Dengan perolehan nilai rata-rata diatas 75 maka penulis dianggap sudah mencapai target yang telah ditentukan. Tindakan pun berakhir di siklus II dan penulis tidak melanjutkan ke siklus berikutnya.

Berdasarkan tabel dan grafik di atas, dapat dilihat bahwa hasil yang didapat oleh 35 siswa kelas IB MI Nurul Anwar mengalami peningkatan dan sudah mencapai kriteria yang telah ditetapkan yakni rata-rata prosentase kelas mencapai 75.

\section{PENUTUP}

Pada siklus I rata-rata adalah $73 \%$, mengalami peningkatan jika dibandingkan dengan nilai rata-rata pada tahap prapenelitian sebesar 49\%. Berdasarkan perbandingan rata-rata prapenelitian dengan siklus I, maka didapat prosentase kenaikan sebesar $24 \%$. Untuk melengkapi penyempurnaan data penelitian dan pencapaian standar KKM yang telah ditentukan yaitu 75 , maka penulis melaksanakan siklus II. Berdasarkan hasil analisis data, pada siklus II terjadi peningkatan hasil rata-rata kelas menjadi $87 \%$, mengalami peningkatan bila dibandingkan dengan rata-rata kelas pada siklus I yaitu 73\%. Berdasarkan perbandingan rata-rata kelas pada siklus I dengan siklus II, maka didapat kenaikan prosentase sebesar $14 \%$.
Dapat dinyatakan bahwa penerapan metode pembelajaran picture and picture dapat meningkatkan hasil. Dapat dinyatakan juga bahwa penerapan metode pembelajaran picture and picture dapat meningkatkan hasil belajar kosakata bahasa Arab. Dengan demikian penulis ini dapat menyimpulkan sebagai berikut.

1. Berdasarkan data catatan lapangan dan lembar tugas siswa yang dilakukan pada setiap siklus pembelajaran, terdapat peningkatan hasil belajar kosakata bahasa Arab disetiap siklus.

2. Kegiatan pembelajaran kosakata bahasa Arab dengan menggunakan metode pembelajaran picture and picture dapat membuat siswa lebih termotivasi dan lebih semangat dalam proses pembelajaran.

3. Selain pemilihan media dan metode yang tepat, latihan menyelesaikan soal baik secara lisan maupun tulisan yang berkesinambungan juga dapat meningkatkan hasil belajar kosakata bahasa Arab siswa diberikan siswa dalam menjawab soal-soal yang diberikan oleh penliti. Karena siswa diberikan waktu yang cukup untuk mempelajari bahan kosakata, sehingga mengurangi kegagalan siswa dalam belajar dan pada akhirnya mendapatkan hasil yang optimal.

4. Metode pembelajaran picture and picture merupakan sebuah metode yang mudah dipakai. Metode ini juga memerlukan sebuah gambar yang sangat bagus.

\section{UCAPAN TERIMA KASIH}

Syukur alhamdulillah penulis ucapkan kepada Allah Subhanahu wa ta'ala karena atas rahmat dan petunjuk-Nya penulis dapat menyelesaian penelitian ini. Tak lupa juga penulis ucapkan terimakasih yang sebesarbesarnya kepada dosen pembimbing yang selalu memberikan arahan dan motivasi kepada penulis. Begitu juga kepada seluruh pihak yang telah memberikan bantuan dan dukungan untuk menyelesaikan penelitian ini. 


\section{REFERENSI}

Arikunto, S. (2013). Prosedur Penelitian Suatu Pendekatan Praktik. Jakarta: Rineka Cipta.

Djiwandono, S. M. (2008). Tes Bahasa. Jakarta: PT. Indeks.

Ekawarna (2010). Penelitian Tindakan Kelas. Jakarta: GP Press.

Hamdayana, J. (2017). Model dan Metode Pembelajaran Kreatif dan Berkarakter. Bogor: Ghalia Indonesia.

Hamid, A. (2010). Mengukur Kemampuan Bahasa Arab. Malang: UIN Maliki Press.

Hasanah, L. (2018). Penggunaan Real Object Dapat Meningkatkan Minat Belajar Sains Anak Usia 5-6 Tahun. EL BANAR: JURNAL PENDIDIKAN DAN PENGAJARAN, 1(01), 13-20.

Hermawan, A. (2014). Metodologi Pembelajaran Bahasa Arab. Bandung: PT. Remaja Rosdakarya.

Nuha, U. (2016). Ragam Metodologi \& Media Pembelajaran Bahasa Arab. Yogyakarta: Diva Press.

Wihardit, K. dan Wardhani, I. (2012). Penelitian Tindakan Kelas. Jakarta: Universitas Terbuka. 